\title{
Enhancement of Tourism Promotion Efforts in DKI Jakarta
}

\author{
Taufiq Rachman \\ STIE Pelita Bangsa, Indonesia \\ tfgman@gmail.com
}

\begin{abstract}
This study discusses about enhancement of tourism promotion efforts in DKI Jakarta. Variables in the study consists of security stability variables and macroeconomic policies, tourism policies and budgets, tourism development strategies, strategies for supporting facilities and infrastructure development, length of stay improvement programs for foreign tourist visits, increased tourist visits to the archipelago, tourism sector MSMEs development, creation Tourism Employment, and Regional Revenue Increase from the Tourism Sector. The object of research is tourism businesses and MSMEs that carry out tourism sector activities in DKI Jakarta. Whereas the subjects in this study were leaders / managers, and MSMEs entrepreneurs, as well as other related parties. The result shows that there is a meaningful relationship between the variables of Security Stability and Macroeconomic Policy, Tourism Policy and Budget, Tourism Object Development Strategy, Tourism Support Facilities and Infrastructure Development Strategy, Length of Stay Program. The lowest closeness of the relationship is the Security Stability and Macroeconomic Policy variables with the Tourism Object Development Strategy variable, while the highest relationship closeness is the Security and Macroeconomic Policy variables, the Policy with the Length of Stay Program Improvement variable.
\end{abstract}

Keywords : enhancement; tourism; promotion; DKI Jakarta

\section{Introduction}

DKI Jakarta is dubbed "A City with Thousands of Opportunities" which in recent decades has been the main entrance of the Asian region with all its uniqueness. Aside from being the administrative center of the capital of Indonesia but also as a center for social, cultural and health activities. Jakarta is a bustling and bustling city filled with land, sea and air transportation facilities. Jakarta was also dubbed "The City Administration" which consisted of 6 (six) regions up to and reaching to the Thousand Islands region. Jakarta as a center for administrative activities consisting of 43 sub-districts and 256 sub-districts, coupled with the community association (RW) and Neighborhood Unit (RT). The city of Jakarta is also the "City of History" which shows the historic city more than 500 years ago where the Ciliwung River flowed. Jakarta has an attraction as a center of trade activities and historical heritage heritage that is interesting to visit. So, Jakarta as "The Trade City" as well as "The tourism and Cultural City", so that Jakarta deserves to be a city that will attract many domestic and foreign tourists from a variety of attractions, activities and tourism attractions. Jakarta is also a major city center (business, trade, entertainment, hotels and restaurants, education, infrastructure, buildings and historic buildings) and is very attractive compared to other major cities throughout the world. Jakarta plays an important role in contributing to the economy and specifically the tourism sector in Indonesia after the Island of the Gods of Bali.

DKI Jakarta's flagship tourism objects according to successive locations such as: Ancol Jaya Dream Park, Beautiful Indonesia Mini Park, Ragunan Animal Temple, National Monument, National Museum, Satria Mandala Museum, Jakarta History Museum and Sunda Kelapa Harbor. From these objects 3 (three) locations as tourist objects classified as visited by tourists such as; Ancol Dreamland Park, Beautiful Indonesia Mini Park and Ragunan Animal Sanctuary. Of the leading tourism objects, the number of tourists has decreased significantly, 
which is down from $22,183,535$ in 2001 to $13,625,122$ in 2005 , down about 38 percent. Data on foreign tourist arrivals in DKI Jakarta according to BPS (2006: p. 453) when compared to the number of Indonesian tourists, the number of DKI tourists is very significant with a percentage of 21-30 percent.

Factors that influence regional income receipts from the tourism industry sector, both from domestic and foreign tourists, will be related to the amount of government budget spent to fund tourism facilities and infrastructure, the size of the budget for promotion both domestically and abroad, besides that influenced by the number of visits made by tourists including the length of stay, the influence of attraction of tourist attractions both in terms of numbers and the advantages of the products offered (tour packages), facilities to reach tourist attractions such as transportation facilities (land, sea, river and air), accommodation in tourist destination locations (hotels, restaurants, souvenir sale places etc.), information provided (catalogs, print media, electronic media and others), other supporting institutions such as bureaus travel, passport services and others.

Regional revenue from the tourism sector directly impacts the availability of activities and small and medium micro business units around the tourism service process to tourism destinations so that this increase in activity can develop Micro, Small and Medium Enterprises (MSMEs) and have the opportunity to increase employment. The number of poor people in Indonesia in 2007 (BPS) reached 37.17 million (16.58\%) with unemployment estimated to reach 10 million workers and partly unemployment in DKI Jakarta ranging from 200,000 with employment opportunities of around 15,000 in 2005. Tourism activities also have a significant influence on the activities of other businesses such as hotels, restaurants, other entertainment facilities, transportation companies, travel agencies, gift shops, and other types and business activities. It is estimated that the impact of business activities in addition to increasing regional revenues DKI Jakarta also increases Micro, Small and Medium Enterprises (MSMEs) and employment which have a direct impact on increasing tourism competitiveness in the Special Capital Region (DKI) of Jakarta.

\subsection{Development Theory}

\section{Review of Literature}

In general, economic development is defined as a series of efforts in an economy to develop its economic activities so that more infrastructure is available, more and more companies are growing, the education level is getting higher and technology is increasing. As an implication of this development, it is expected that employment opportunities will increase, income levels increase, and community prosperity will be increasingly high (Sadono Sukirno, 2006: p. 3).

According to the strict academic understanding of economics in Todaro (2000, p. 17) translated by Haris Munandar, the term development (development) has traditionally been interpreted as the capacity of a national economy whose initial economic conditions are more or less static in a sufficient period of time long time to create and maintain an annual increase in gross national income or Gross National Product.

According to Meiyer and Baldwin in Suryana (2000, p. 3):

Economics development is a process of the economy of real national income increasing on a long period of time. And if the rate of development is great than the rate of population growth, then per capita real income increase 
Economic development is defined as a process that causes per capita income of a population to increase in the long run. From this definition it contains three elements: (1) economic development as a process means continuous change in which it contains its own elements of strength for new investments; (2) efforts to increase per capita income; (3) the increase in per capita income must take place in the long term.

\subsection{Tourism}

Tourism according to McIntosh and Shashikant Gupta in Nyoman S. Pendit (2006, p. 34) a combination and symptoms and relationships that arise and interactions of tourists, business, host governments and host communities in the process of attracting and serving tourists and other visitors .

Tourism according to Lumsdon (1997) is a managerial process that anticipates and satisfies the desires of existing and more prospective visitors and suppliers or competitors' destinations. Management changes are driven by profits and benefits for the community or both; whichever path is taken, long-term success depends on the interaction between the customer and the supplier. This also means saving the needs of the environment and society and is at the core of customer satisfaction. These things can no longer be considered as something separate from each other.

Tourism according to Regional Regulation No. 10 of 2004 concerning Tourism in Article 1 is a travel activity or part of the activity carried out voluntarily and temporarily to enjoy a destination.

Tourism according to Law No. 10 of 2009 concerning Tourism in Article 1 is a travel activity carried out by a person or group of people by visiting certain places for recreational purposes, personal development, or studying the tourist attractions visited in the interim period.

Tourism according to Regional Regulation No. 10 of 2004 concerning Tourism is everything related to tourism, including the exploitation of tourism attractions and related businesses in that field. Tourism according to Law No. 10 of 2009 concerning Tourism is a variety of tourism activities and is supported by various facilities and services provided by the community, entrepreneurs, government and regional governments.

Tourism Marketing according to Regional Regulation No. 10 of 2004 concerning Tourism is an effort to introduce, promote and sell tourism products and destinations both domestically and abroad.

Seaton and Benett (1996) identified 5 (five) important characteristics of tourism marketing, namely:

1) A consumer-oriented philosophy

2) Analytical procedures and criteria

3) Data collection techniques

4) Organizational structure

5) Regional strategic decisions and planning functions.

According to Wahab (2003: p. 9) tourism is an important factor to mobilize the unity of the nation and its people who have different regions, dialects, customs and diverse tastes as well.

Tourists according to Hunziker and Krapft in Nyoman S.Pendit (2006, p. 35) a number of relationships and symptoms that result from the stay of foreigners, provided that their stay does not cause temporary residence and efforts or permanent as a business looking for full employment. 
Travelers according to J. Christopher Holloway in Nyoman S.Pendit (2006, p. 33) are someone who travels to see something else and then complains if he pays something that is not appropriate.

International tourism is very useful as a means to increase international understanding and as a tranquilizing tool in political tensions because if people from various countries meet and pay attention to their household life patterns (at least this is what happens), then surely they will mutual understanding better.

\subsection{Competitiveness of the Tourism Sector}

According to Porter (1994: 1), competition is the essence of success or failure. Competition determines the accuracy of organizational activities that can support performance such as innovation, cohesive culture or good implementation. A competitive strategy is the search for competitive positions that are profitable within an industry, the fundamental arena in which competition occurs. Competitive strategies aim to establish a position that is profitable and can be defended against the forces that determine industrial competition.

The definition of competitiveness at the national level is the degree to which the country, in free and fair market conditions, can produce goods and services that meet international market testing while simultaneously increasing the real income of its citizens. Competitiveness at the national level is based on superior productivity performance. (Report of the President's Competitiveness Commission, written for the Reagan administration in 1984 in Dong-Sung Cho and Hwy-Chang Moon, 2003; 246)

According to Porter $(1994 ; 4)$, in any industry, both domestically and internationally or producing products or services, competition rules include within 5 (five) competing forces, namely:
a. The entry of new competitors.
b. Threats of substitute products (substitution).
c. Power of bargaining (bargaining) of buyers.
d. Power of supplier bidding.
e. Competition among existing competitors.

\section{Research Method}

Variables in the study consists of security stability variables and macroeconomic policies, tourism policies and budgets, tourism development strategies, strategies for supporting facilities and infrastructure development, length of stay improvement programs for foreign tourist visits, increased tourist visits to the archipelago, tourism sector MSMEs development, creation Tourism Employment, and Regional Revenue Increase from the Tourism Sector

The object of research is tourism businesses and MSMEs that carry out tourism sector activities in DKI Jakarta. Whereas the subjects in this study were leaders / managers, and MSMEs entrepreneurs, as well as other related parties.

\section{Discussion}

Promotional activities carried out by the Tourism Office in 2008 have been carried out a lot, both in the form of participation in international level tourism exhibitions and national level 
tourism exhibitions, as well as advertising in national and international media as seen in the activities below:

\subsection{Domestic Promotion}

In 2008, the Tourism Office's domestic promotional activities were divided into two groups, namely regular activities at the national tourism exhibition and the activities of the Jakarta Tourism Expo in several tourist centers, as shown in table 1 below:

Table 1. List of Domestic Promotion Activities 2008

\begin{tabular}{|c|c|c|c|}
\hline NO & TIME & ACTIVITIES & PLACE \\
\hline 1 & 16-20 May 2008 & Jogja Art and Tourism & Jogjakarta \\
\hline 2 & 20-25 May 2008 & Majapahit Travel Fair & Surabaya \\
\hline 3 & 7-17 August 2008 & Padang Fair & Padang, Sumbar \\
\hline 4 & 19-24 August 2008 & Manado Expo & Manado \\
\hline 5 & 20-25 August 2008 & NTB Expo & Mataram \\
\hline 6 & 26-31 August 2008 & Festival Krakatau & Lampung \\
\hline 7 & $10-14$ Oct 2008 & Festival Nusa Dua & Bali \\
\hline 8 & 23-26 Oct 2008 & Kemilau Nusantara & Bandung \\
\hline 9 & 18-21 Nov 2008 & Jakarta Tourism Expo & Medan \\
\hline 10 & 2-5 December 2008 & Jakarta Tourism Expo & Surabaya \\
\hline
\end{tabular}

Source: Subdis of Marketing and International Relations

\subsection{Foreign Promotion}

The following are some overseas promotional activities programmed in the Marketing and International Relations Sub-Department for the 2008 financial year, as shown in table 2:

Table 2. List of Overseas Promotional Activities 2008

\begin{tabular}{|l|l|l|l|}
\hline \hline NO & TIME & ACTIVITIES & PLACE \\
\hline \hline 1 & 19-26 March 2008 & Jakarta Food \& Culture Festival & Istambul, Turki \\
\hline 2 & 6-9 May2008 & Arabian Travel Market (ATM) & Dubai, Uni Emirat Arab \\
\hline 3 & 5-8 June 2008 & Korean Travel Fair (KOTFA) & Seoul, Korea Selatan \\
\hline 4 & 12-15 June 2008 & International Travel Expo (ITE) & Hongkong, China \\
\hline 5 & 2-4 August 2008 & Outbound Travel Market (OTM) & Calcutta, India \\
\hline 6 & 5-7 Sept 2008 & MATTA Fair II & $\begin{array}{l}\text { Kuala } \\
\text { Malaysia }\end{array}$ \\
\hline
\end{tabular}




\begin{tabular}{|l|l|l|l|}
\hline 7 & 19-21 Sept 2008 & JATA-World Travel Fair & Tokyo, Jepang \\
\hline 8 & 7-9 October 2008 & ITCMA (MICE) & Bangkok, Thailand \\
\hline
\end{tabular}

Source: Subdis of Marketing and International Relations

\subsection{Media and Communication}

To support Jakarta tourism promotion activities both domestically and abroad, advertising activities have been carried out in print and foreign media, making Jakarta souvenirs and printing promotional materials both at home and abroad, but at the time of data collection, communication media activities have not done.

\subsection{International Relations}

International Relations Activities The Jakarta tourism office includes active participation in several meeting events with members of international tourism both at regional and regional levels, including:

Table 3. List of International Relations Activities 2008

\begin{tabular}{|c|c|c|c|}
\hline NO & TIME & ACTIVITIES & PLACE \\
\hline 1 & 29 April - 3 May & $\begin{array}{l}\text { TPO Executive } \\
\text { Meeeting }\end{array}$ & $\begin{array}{l}\text { Melbourne, } \\
\text { Australia }\end{array}$ \\
\hline 2 & 5-9 October & $\begin{array}{l}\text { TPO Forum and The World } \\
\text { Tourism Investment }\end{array}$ & $\begin{array}{l}\text { Busan. } \\
\text { Korea Selatan }\end{array}$ \\
\hline 3 & 6-10 October & $\begin{array}{l}\text { The Council For Promotion of } \\
\text { Tourism in Asia (CPTA) }\end{array}$ & Hanoi, Vietnam \\
\hline 4 & October & $\begin{array}{l}\text { International Congress } \quad \text { and } \\
\text { Convention Assoc. }\end{array}$ & Kanada \\
\hline \multicolumn{4}{|c|}{ FAM TRIP } \\
\hline 1 & 10 June & $\begin{array}{l}\text { Garuda Indonesia Tokyo (15 orang } \\
\text { Tour Operator) }\end{array}$ & Jakarta \\
\hline 2 & 9-11 September & KL Media fam Trip (15 jurnalis) & Jakarta \\
\hline 3 & 10-11 September & $\begin{array}{l}\text { Singapore } \\
\begin{array}{l}\text { Airlines } \\
\text { Indonesia fam Trip to } \\
\text { countries (15 orang) }\end{array}\end{array}$ & Jakarta \\
\hline 4 & 26-28 September & FEALAC (7 jurnalis) & Jakarta \\
\hline 5 & 22-25 October & Journalist visit programme & Jakarta \\
\hline 6 & 10-12 November & $\begin{array}{l}\text { Fam Trip Crew film } 3 \text { dimensi } \\
\text { Garuda Indonesia Jepang }\end{array}$ & Jakarta \\
\hline 7 & 25-29 November & Fam Trip TV ATN Bangladesh & Jakarta \\
\hline
\end{tabular}

Source: Subdis of Marketing and International Relations

\subsection{Expected Impact}

The tourism development of DKI Jakarta province refers to the strategic plan of the DKI Jakarta province as stipulated in the DKI Jakarta Provincial Regulation Number 10 of 2002 
concerning the Strategic Plan (Renstra) of the DKI Jakarta Province. Based on the regulation, the activities of all tourism units in the DKI Jakarta Provincial Tourism Office were prepared, both in the form of a one-year program such as the 2008 work program and a five-year strategic plan. The plan is contained in three main programs, namely; Tourism Product Development, Tourism Market Development, and Tourism Facilities and Services Development. Plus, it must be adjusted to each Tourism Office work program that refers to the Regional Medium Term Development Plan (RPJMD), in order to further optimize the performance targets of all activities.

In general, the implementation of many tourism program activities experienced problems, especially in terms of disbursement of funds due to delays in the new APBD which was ratified in April 2008, but until June 2008 it was still undergoing changes and awaiting approval from the legislature. This has resulted in the resignation of the schedule for holding several tourism events in Jakarta, which was held by the Jakarta Tourism Office.

The expected impact of the results and analysis of the preparation of the Jakarta tourism data for 2008, can be used as a reference in making tourism development policies in Jakarta both related to the readiness of tourism products, promotion and communication strategies, and guidance to the tourism industry. Of the overall data, the most concerning is data on tourism products in the Thousand Islands which have ups and downs, and impact on the closure of the tourism industry, if this is allowed then gradually the tourism business in the Thousand Islands will be difficult to become a mainstay of Jakarta tourism as a natural tourism product which is the pride of Jakarta.

\subsection{Average Length of Stay of Tourists in Jakarta}

The following data are presented on the average length of stay of foreign tourists in Jakarta based on surveys of expenditure and satisfaction of foreign guests conducted by the Jakarta Central Bureau of Statistics in 2006, as in table 4 below:

Table 4. Average Length of Stay of Foreign Tourists in Jakarta In 2007

\begin{tabular}{|l|l|l|}
\hline \hline No & The Main Job & Average Length of Stay (Days) \\
\hline 1. & Professional & 5,36 \\
\hline 2. & Business / Executive & 4,83 \\
\hline 3. & Government Employees & 7,89 \\
\hline 4. & Military & 8,82 \\
\hline 5. & International Organization & 5,62 \\
\hline 6. & Employee & 6,63 \\
\hline 7. & Ibu Rumah Tangga & 7,83 \\
\hline 8. & Student & 9,41 \\
\hline 9. & Retired & 8,47 \\
\hline 10. & LSM & 6,05 \\
\hline 11. & Other & 7,09 \\
\hline & Average & $\mathbf{7 , 0 9}$ \\
\hline
\end{tabular}

Souce: BPS 2006 


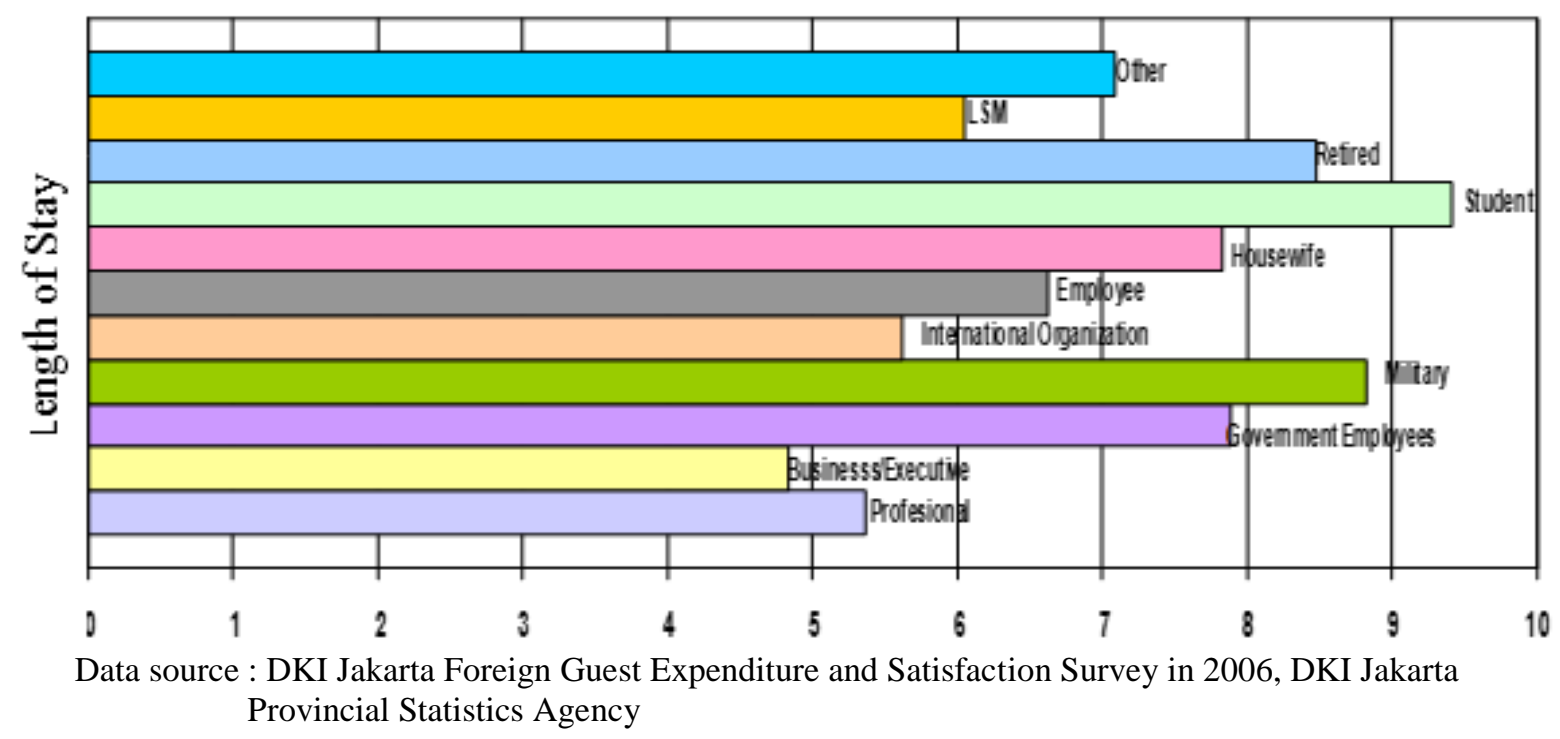

\subsection{Average Expenditures of Foreign Travelers in Jakarta}

Based on data from the 2008 Department of Culture's Passenger Exit Survey, it can be described the data on the average expenditure of foreign tourists per visit according to the country of residence and exit as follows:

Table 5. Average Expenditures of Wisdom Per Visit According to Residence and Exit in 2007 Unit: \$ US

\begin{tabular}{|l|l|}
\hline \hline COUNTRY OF RESIDENCE & Pintu Keluar Soekarno-Hatta \\
\hline Brunei Darussalam & 570.04 \\
\hline Malaysia & 658.98 \\
\hline Filipina & 713.04 \\
\hline Singapura & 665.17 \\
\hline Thailand & 921.10 \\
\hline Hong Kong & 772.88 \\
\hline India & $1.075,51$ \\
\hline Jepang & 945,69 \\
\hline Korea Selatan & 824,91 \\
\hline Pakistan & 899,22 \\
\hline Bangladesh & $1.365,83$ \\
\hline Srilanka & 750,68 \\
\hline Taiwan & 767,53 \\
\hline China & 820,79 \\
\hline Saudi Arabia & $1.661,57$ \\
\hline Asia Lainnya & $1.419,55$ \\
\hline Total Asia & 824,09 \\
\hline Austria & $1.221,16$ \\
\hline Belgia & $1.012,87$ \\
\hline Denmark & 533,50 \\
\hline Perancis & $1.356,38$ \\
\hline Jerman & $1.161,53$ \\
\hline & 399 \\
\hline https://doi.org/10.33258/birci.v2i2.313 & \\
\hline
\end{tabular}




\begin{tabular}{|l|l|} 
Italia & $1.121,92$ \\
\hline Belanda & $1.235,42$ \\
\hline Spanyol \& Portugal & $2.728,61$ \\
\hline Swedia & 908,81 \\
\hline Swiss & $1.829,12$ \\
\hline Inggris & $1.383,67$ \\
\hline Finlandia & $1.269,17$ \\
\hline Norwegia & $1.170,14$ \\
\hline Rusia & $1.942,68$ \\
\hline Eropa Lainnya & $1.073,00$ \\
\hline Total Eropa & $1.277,06$ \\
\hline Amerika Serikat & $1.554,28$ \\
\hline Kanada & $1.029,52$ \\
\hline Mexico & $2.500,00$ \\
\hline Amerika Tengah & - \\
\hline Amerika Selatan & $1.435,00$ \\
\hline Total Amerika & $1.466,45$ \\
\hline Australia & $1.206,77$ \\
\hline Selandia Baru & $1.107,17$ \\
\hline Oseania lainnya & 737,20 \\
\hline Total Oseania & $1.194,11$ \\
\hline Mesir & 900,83 \\
\hline Afrika Lainnya & $1.021,12$ \\
\hline Total Afrika & $1.004,34$ \\
\hline \hline Average & $\mathbf{1 . 0 0 0 , 8 2}$ \\
\hline \hline Sumber Pasenger Exit Surve 2007, & \\
\hline
\end{tabular}

Sumber : Passenger Exit Survey 2007, Departemen Kebudayaan dan Pariwisata

From table 5. the following is illustrated the ranking of the average expenditure of foreign tourists according to the country of residence from the Soekarno-Hatta exit, data shows that the countries of Spain and Portugal are ranked number 1 followed by Mexico and Russia. This means that the foreign tourist market that has not been cultivated so far turns out to have large spending power compared to tourists from ASEAN and East Asia. Foreign tourists from Bangladesh who received less attention as the target market actually ranked 8th where other Asian countries actually did not become the biggest expenditure contributor.

In addition, countries such as Finland, South America and Mexico that have not become the target market for Jakarta, need to be analyzed further the opportunity as a potential tourism market for Jakarta. For countries in the Middle East, Saudi Arabia sits in the top 10 while other Arab countries may still be difficult in calculating visits because the numbers are still low.

Table 6 Average Expenditures of Foreign Tourists Per Visit According to Country of Residence and Soekarno-Hatta Exit in 2007

\begin{tabular}{|l|c|c|}
\hline \multicolumn{1}{|c|}{ Country of Residence } & $\begin{array}{c}\text { TotalH/Day } \\
\text { US \$ }\end{array}$ & Rating \\
\hline Spany ol dan Portugal & 2728,61 & 1 \\
\hline Mexico & 2500 & 2 \\
\hline Rusia & 1942,68 & 3 \\
\hline Saudi Arabia & 1661,57 & 4 \\
\hline
\end{tabular}




\begin{tabular}{|l|c|c|}
\hline Amerika Serikat & 1554,28 & 5 \\
\hline Amerika Selatan & 1435 & 6 \\
\hline Inggris & 1383,67 & 7 \\
\hline Bangladesh & 1365,83 & 8 \\
\hline Perancis & 1356,38 & 9 \\
\hline Finlandia & 1269,17 & 10 \\
\hline
\end{tabular}

Source : Passenger Exit Survey (Depbudpar, 2007)

As for the average expenditure of foreign tourists per day according to the country of residence and exit, foreign tourists from Bangladesh (1) with expenditures per day of 273.17 USD, Switzerland (2) with an average of 159.05 as shown in the table below:

Table 7. Average Expenditures of Wisman Per Day According to Country of Residence and Exit of 2007 Unit: US \$

\begin{tabular}{|l|l|l|}
\hline Country of Residence & Exit of Soekarno Hatta & Rating \\
\hline Brunei Darussalam & 110,98 & \\
\hline Malaysia & 116,59 & \\
\hline Filipina & 96,46 & $\mathbf{9}$ \\
\hline Singapura & $\mathbf{1 3 1 , 9 5}$ & $\mathbf{4}$ \\
\hline Thailand & $\mathbf{1 5 4 , 3 9}$ & \\
\hline Hong Kong & 111,85 & \\
\hline India & 108,14 & \\
\hline Jepang & 114,59 & \\
\hline Korea Selatan & 114,54 & \\
\hline Pakistan & 93,52 & $\mathbf{1}$ \\
\hline Bangladesh & $\mathbf{2 7 3 , 1 7}$ & $\mathbf{3}$ \\
\hline Srilanka & $\mathbf{1 5 6 , 8 6}$ & \\
\hline Taiwan & 100,99 & \\
\hline China & 116,56 & $\mathbf{7}$ \\
\hline Arab Saudi & $\mathbf{1 3 6 , 5 5}$ & \\
\hline Asia Lainnya & 178,86 & \\
\hline Total Asia & 124,62 & \\
\hline Austria & 86,66 & $\mathbf{2}$ \\
\hline Belgia & 77,34 & \\
\hline Denmark & 52,05 & \\
\hline Perancis & 88,44 & \\
\hline Jerman & 90,33 & \\
\hline Italia & 87,65 & \\
\hline Belanda & 65,74 & \\
\hline Spanyol \& Portugal & $\mathbf{1 2 0 , 0 0}$ & \\
\hline Swedia & 113,60 & $\mathbf{1 5 9 , 0 5}$ \\
\hline Swiss & 97,82 & \\
\hline Inggris & 90,65 & \\
\hline Finlandia & 100,87 & \\
\hline Norwegia & & \\
\hline & & \\
\hline
\end{tabular}




\begin{tabular}{|c|c|c|}
\hline Rusia & 138,76 & 6 \\
\hline Eropa Lainnya & 82,86 & \\
\hline Total Eropa & 88,17 & \\
\hline Amerika Serikat & 132,75 & 8 \\
\hline Kanada & 92,87 & \\
\hline Mexico & 80,65 & \\
\hline Amerika Tengah & - & \\
\hline Amerika Selatan & 80,00 & \\
\hline Total Amerika & 121,23 & \\
\hline Australia & 115,28 & \\
\hline Selandia Baru & 94,73 & \\
\hline Oseania lainnya & 110,58 & \\
\hline Total Oseania & 113,70 & \\
\hline Mesir & 150,14 & 5 \\
\hline Afrika Lainnya & 107,33 & \\
\hline Total Afrika & 111,31 & \\
\hline Rata-rata & 110,46 & \\
\hline
\end{tabular}

Source : Passenger Exit Survey 2007, Ministry of Culture and Tourism

From the table above, it can be seen that most tourists who have the highest average daily expenditure are not the main target market for tourists for Jakarta. Therefore, it is necessary to consider the country of origin of tourists who have high spending power and what efforts can be made to extend the length of stay they live in Jakarta, so that foreign exchange earnings increase. Tourists from Bangladesh and Sri Lanka have not even been considered potential tourist markets for Jakarta. Foreign tourists from Switzerland, Russia, Spain and Portugal who are not targeted as markets need to be directed and used as new markets in the European region because of their high purchasing power. As for the tourist market in the ASEAN region, Singaporeans have often become the target market and especially for Singapore tourists who spend the weekend in Jakarta, which is interesting that foreign tourists from Thailand are ranked fourth, this means that geographical proximity to Jakarta and tourism product development efforts different cities than those offered by Bangkok, Jakarta will be a pleasant place for Thais.

Based on the results of the 2007 Passenger Exit Survey, Ministry of Culture and Tourism, the average length of stay of foreign tourists per visit according to the country of residence of the Soekarno-Hatta exit, has an average length of stay of 8.09 days (data as attached). Foreign tourists from South Africa have a stay of 15.38 days and the least length of stay is foreign tourists from Pakistan with a length of stay of 4.33 days. From the average length of stay of foreign tourists 8.09 days, those who live purely in the DKI Jakarta Province are with an average proportion of 5.11 days.

While the average expenditure of foreign tourists per day according to the country of residence and exit in 2007, are as follows: 
Table 8. Average Expenditures of Foreign Tourists Per Day According to Country of Residence and Exit in 2007

\begin{tabular}{|c|c|c|c|}
\hline \multirow[b]{2}{*}{ Country of Residence } & \multicolumn{3}{|c|}{ EXIT } \\
\hline & $\begin{array}{c}\text { Soekarno-Hatta } \\
\text { (JKT) }\end{array}$ & $\begin{array}{c}\text { Ngurah Rai } \\
\text { (BALI) }\end{array}$ & $\begin{array}{c}\text { Juanda } \\
\text { (SBY) }\end{array}$ \\
\hline ASEAN & 138,16 & 145,64 & 89,72 \\
\hline Asia (Kecuali ASEAN) & 130,94 & 130,98 & 83,79 \\
\hline Timur Tengah & 158,49 & 214,78 & 112,50 \\
\hline Eropa & 112,34 & 93,17 & 79,03 \\
\hline Amerika & 141,07 & 100,27 & 96,67 \\
\hline Oseania & 115,46 & 104,58 & 52,09 \\
\hline Afrika & 109,24 & 89,43 & 143,43 \\
\hline
\end{tabular}

Source : Passenger Exit Survey (Ministry of Culture and Tourism, 2007)

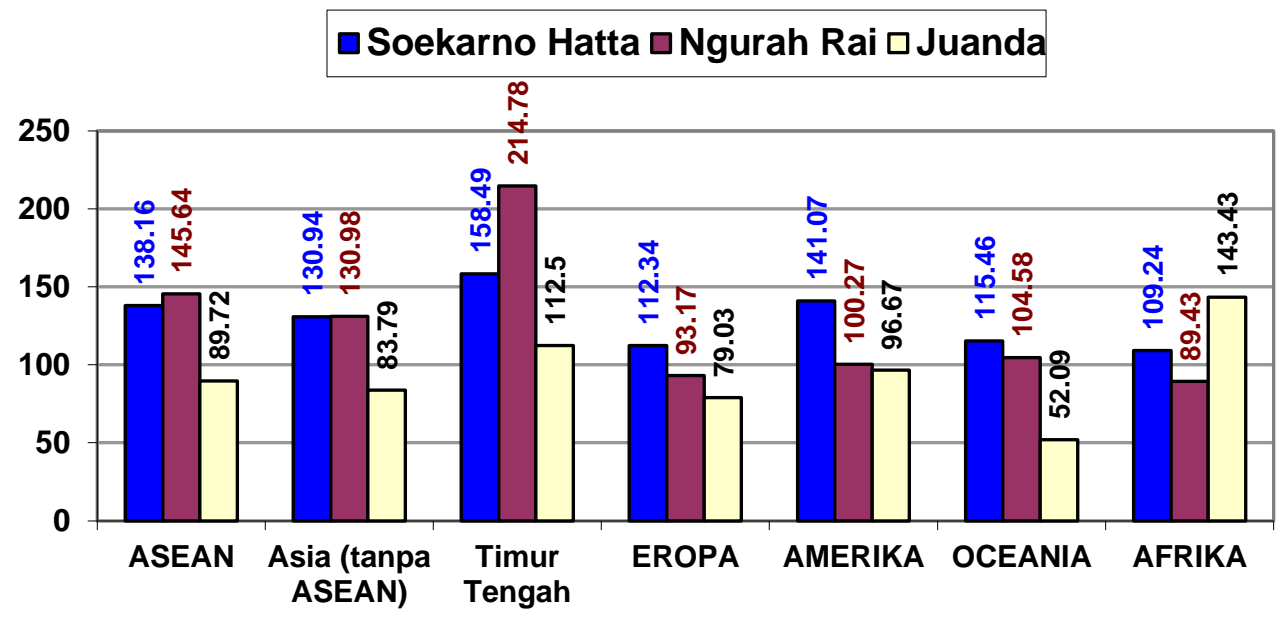

Figure 2. Average Expenditures of Foreign Experts Per Day by Country of Residence and Exit in 2007

Source: Passenger Exit Survey (Ministry of Culture and Tourism, 2007)

\subsection{Average Length of Stay for Tourists at a Starry Hotel in Jakarta}

In this section, data will be drawn on the average length of stay of foreign tourists in starrated hotels in Jakarta, as input for reviewing the position of product supply in Jakarta, especially from accommodation and the comparison with the number of available rooms. So that later it will be known whether the accommodation facilities in Jakarta are over supply or require more rooms to receive foreign tourist visits.

The highest occupancy rate for foreign tourist rooms in 2008 was in August (56.96\%) and April (56.41\%). What needs to be paid attention to is that April and August are not the peak season for Jakarta, this is probably because in those months many exhibitions, meeting activities / MICE for business travelers were held, along with data on room occupancy rates for 2006-2008 : 
Table 9. Average Occupancy Rate of Mancanegar Tourist Rooms in Starred Hotels in DKI Jakarta 2006-2008

\begin{tabular}{|l|l|l|l|l|l|}
\hline MONTH & $\begin{array}{l}\text { YEAR } \\
\mathbf{2 0 0 6} \\
(\boldsymbol{\%})\end{array}$ & $\begin{array}{l}\text { YEAR } \\
\mathbf{2 0 0 7} \\
(\boldsymbol{\%})\end{array}$ & $\begin{array}{l}\text { DEVELO } \\
\text { PMENT } \\
(\boldsymbol{\%} *)\end{array}$ & $\begin{array}{l}\text { YEAR } \\
\mathbf{2 0 0 8} \\
(\boldsymbol{\%})\end{array}$ & $\begin{array}{l}\text { DEVELO } \\
\text { PMENT } \\
(\boldsymbol{\%} * *)\end{array}$ \\
\hline \hline January & 42,91 & 58,00 & 15,09 & 52,29 & $(5,71)$ \\
\hline February & 46,39 & 57,39 & 11 & 50,98 & $(6,41)$ \\
\hline March & 52,17 & 52,07 & $(0,1)$ & 52,03 & $(0,04)$ \\
\hline April & 48,93 & 53,82 & 4,89 & 56,41 & 4,38 \\
\hline May & 50,79 & 53,74 & 2,95 & 55,20 & $(1,21)$ \\
\hline June & 49,00 & 57,84 & 8,84 & 53,94 & $(1,26)$ \\
\hline July & 54,91 & 59,09 & 4,18 & 56,29 & $(2,80)$ \\
\hline Agustus & 49,15 & 54,57 & 5,42 & 56,96 & 2,39 \\
\hline September & 56,34 & 50,20 & $(6,14)$ & 42,96 & $(7,24)$ \\
\hline October & 44,28 & 50,86 & 6,58 & 43,59 & $(7,27)$ \\
\hline November & 53,77 & 58,97 & 5,2 & 49,30 & $(9,67)$ \\
\hline December & 60,89 & 59,05 & $(1,84)$ & 50,33 & $(8,72)$ \\
\hline Average & $\mathbf{5 0 , 7 9}$ & $\mathbf{5 5 , 4 7}$ & $\mathbf{4 , 6 7}$ & $\mathbf{5 1 , 6 9}$ & $(\mathbf{3 , 6 3 )}$ \\
\hline
\end{tabular}

*: growth in room occupancy rates compared to the same month in 2007 with 2006 **: growth in room occupancy rates in 2008 compared to the same month in 2007 Source: BPS DKI Jakarta Province

Table 10. Average Length of Stay of Foreign Tourists in Starred Hotels in DKI Jakarta 20052008 Unit: Days

\begin{tabular}{|l|l|l|l|l|}
\hline MONTH & YEAR 2005 & $\begin{array}{l}\text { YEAR } \\
\mathbf{2 0 0 6}\end{array}$ & $\begin{array}{l}\text { YEAR } \\
\mathbf{2 0 0 7}\end{array}$ & $\begin{array}{l}\text { YEAR } \\
\mathbf{2 0 0 8}\end{array}$ \\
\hline January & 1,96 & 1,98 & 2,45 & 2,93 \\
\hline February & 1,94 & 1,85 & 2,23 & 3,29 \\
\hline March & 1,90 & 2,26 & 2,52 & 2,79 \\
\hline April & 1,73 & 2,45 & 2,15 & 2,42 \\
\hline May & 1,82 & 2,03 & 2,62 & 2,61 \\
\hline June & 1,71 & 2,00 & 2,49 & 2,39 \\
\hline July & 1,82 & 2,24 & 2,40 & 3,08 \\
\hline Agustus & 2,05 & 2,05 & 2,47 & 2,80 \\
\hline September & 2,04 & 1,96 & 2,84 & 2,81 \\
\hline October & 2,38 & 2,05 & 2,59 & 2,83 \\
\hline November & 2,74 & 2,10 & 2,30 & 4,69 \\
\hline December & 2,12 & 2,28 & 2,65 & 1,99 \\
\hline Source BPS DK Jar
\end{tabular}

Source: BPS DKI Jakarta Province

The average length of stay of foreign tourists in star-rated hotels in Jakarta from 2005 to 2008 on average has increased from an average of less than two days to more than two days. changes in length of stay of foreign tourists for 2008 occurred in February and July 2008, compared to 2007 the average length of stay of tourists experienced a peak in May and September, this indicates a shift in the time or holiday season of tourists to Jakarta. 
For 2008, in February and September many international events such as International Java Jazz festivals and international golf tournaments were held in addition to the many exhibitions and MICE events held in those months. Conversely, if viewed from the average occupancy rate of rooms by foreign tourists, the highest room occupancy rate in 2008 was in August (56.96\%) and April (56.41\%) even though these months were not the peak season for Jakarta. So it is necessary to do further analysis on the changing trend of foreign tourists to Jakarta in order to anticipate and support the promotion and sales of tour packages in Jakarta.

Furthermore, the following will describe the length of stay of foreign tourists in Jakarta according to their main occupation, which was obtained from the Guest Satisfaction and Expenditure survey of the DKI Jakarta Provincial Statistics Agency, and will later be used to calculate foreign exchange earned in the following table:

Table 11. Average Length of Stay, Expenditures Per Visit and Per Day of Tourists Visiting Jakarta by Major Job In 2006

\begin{tabular}{|l|l|l|l|l|}
\hline \hline No & Job & $\begin{array}{l}\text { Average } \\
\text { Length of } \\
\text { Stay (Days) }\end{array}$ & $\begin{array}{l}\text { Average } \\
\text { Expenditures } \\
\text { per Visit (US } \\
\mathbf{\$})\end{array}$ & $\begin{array}{l}\text { Average } \\
\text { Expenditures per } \\
\text { Visit Per Day (US\$) }\end{array}$ \\
\hline \hline 1 & Professional & 5,36 & 914,33 & 170,58 \\
\hline 2 & Business / Executive & 4,83 & 928,83 & 192,51 \\
\hline 3 & Government employees & 7,89 & $1.344,95$ & 170,46 \\
\hline 4 & Military & 8,82 & $1.096,76$ & 124,35 \\
\hline 5 & $\begin{array}{l}\text { International } \\
\text { Organization }\end{array}$ & 5,62 & $1.964,15$ & 189,35 \\
\hline 6 & Employee & 6,63 & 849,15 & 128,08 \\
\hline 7 & Haousewife & 7,83 & $1.230,30$ & 157,13 \\
\hline 8 & Student & 9,41 & 974,27 & 103,54 \\
\hline 9 & Retired & 8,47 & $1.035,68$ & 122,28 \\
\hline 10 & LSM & 6,05 & $1.435,55$ & 237,28 \\
\hline 11 & Other & 7,09 & $1.049,51$ & 148,03 \\
\hline & Average & $\mathbf{7 , 0 9}$ & $\mathbf{1 . 1 6 5 , 7 7}$ & $\mathbf{1 5 8 , 5 1}$ \\
\hline \hline
\end{tabular}

Source: 2006 DKI Jakarta Foreign Guest Expenditure and Satisfaction Survey, DKI Jakarta Provincial Statistics Agency

From the table above, the compiler tries to calculate the foreign exchange generated from the arrival of foreign tourists to Jakarta using the data above, as illustrated in the following table: 
Table 12. Foreign Exchange of Foreign Tourists in DKI Jakarta Province 2002 - 2008

\begin{tabular}{|l|l|l|l|l|}
\hline Year & $\begin{array}{c}\text { Number of } \\
\text { Travelers }\end{array}$ & $\begin{array}{c}\text { Average } \\
\text { Length of } \\
\text { Stay (Day) }\end{array}$ & $\begin{array}{c}\text { Average } \\
\text { Shopping per } \\
\text { Day (US\$) }\end{array}$ & $\begin{array}{c}\text { Amount of } \\
\text { Shoppping (US\$) }\end{array}$ \\
\hline 2002 & 1.267 .695 & 4.80 & 91.38 & $556.041 .451,68$ \\
\hline 2003 & 1.125 .168 & 4.50 & 96.66 & $489.414 .324,96$ \\
\hline 2004 & 1.065 .495 & 5.71 & 100.45 & $611.682 .992,28$ \\
\hline 2005 & 1.168 .656 & 6.31 & 108.54 & $800.397 .769,33$ \\
\hline 2006 & 1.216 .132 & 7,09 & 158,51 & $1.366 .732 .800,74$ \\
\hline 2007 & 1.216 .057 & 5,11 & 120 & $745.686 .152,4$ \\
\hline 2008 & 1.534 .785 & 4 & 120 & $736.696 .800,0$ \\
\hline
\end{tabular}

Source: BPS DKI Jakarta

Processed: DKI Jakarta Provincial Tourism Office

\section{Conclusion}

There is a meaningful relationship between the variables of Security Stability and Macroeconomic Policy, Tourism Policy and Budget, Tourism Object Development Strategy, Tourism Support Facilities and Infrastructure Development Strategy, Length of Stay Program. The lowest closeness of the relationship is the Security Stability and Macroeconomic Policy variables with the Tourism Object Development Strategy variable, while the highest relationship closeness is the Security and Macroeconomic Policy variables, the Policy with the Length of Stay Program Improvement variable. There are effects both partially and simultaneously from the variables of Security Stability and Macroeconomic policies, Tourism Policies and Budgets, Tourism Object Development Strategies, Supporting Facilities and Infrastructure Development Strategies, Length of Stay Improvement Program to Increase Amount and Expenditures for Foreign Tourists in DKI Jakarta very significant. The biggest influence is Security Stability and Macroeconomic policies, while the least influential is the Length of Stay Program.

\section{References}

Badan Pusat Statistik DKI Jakarta 2006 \& 2007, Statistik Ekonomi Indonesia, JakartaIndonesia.

Badan Pusat Statistik (BPS), 2006. Jakarta Dalam Angka. Katalog BPS.1403.31. Jakarta.

Badan Pusat Statistik (BPS), 2006. Statistical Year Book of Indonesia. Katalog BPS.1401. Jakarta.

Badan Pusat Statistik (BPS), 2006. Statistik 60 Tahun Indonesia Merdeka. Katalog BPS.1187. Jakarta.

Badan Pusat Statistik (BPS), 2007. Berita Resmi Statistik. No. 38/07/Th. X, 2 July 2007. Jakarta. 
Baldwin R.E. Meiyer. 1981. Pembangunan dan Pertumbuhan Ekonomi di Negara-Negara Sedang Berkembang. Bina Aksara, Jakarta.

Buku Panduan. Penulisan Disertasi Program Doktor Pascasarjana Universitas Borobudur. 2003.

Cole, Stroma. 1997. Cultural Heritage Tourism. The Villagers's Prespective : A Case Srudy from Ngada, Flores. In Nuryanti (ed). Tourism and Heritage Management. Gadjah Mada University Press. Yogyakarta.

Damanik, Janianton dan Weber, Helmut F. 2006. Perencanaan Ekowisata. Dari Teori ke Aplikasi. Pusat Studi Pariwisata (Puspar) UGM dan Penerbit Andi, Yogyakarta.

Dong-Sung Cho dan Hwy-Chang Moon, 2003. From Adam Smith to Michael Porter. Evolusi Teori Daya Saing. Penerjemah : Erly Suandy. Penerbit Salemba Empat, Jakarta.

Faurastie, Jean, 1967. Reflexions Prospectives Sur La Civilisation des Loisirs, La Civilisation des Loisirs. Marabout Universitie.

Martana, Salmon Priaji. 2002. The Impact of Tourism on the Development of Ubud Painting Art. Volume 1, Number 2, July 2002. ASEAN Journal on Hispitality and Tourism and Centre for Tourism Research, Institut Teknologi Bandung.

Mills, Allan. 2002. Tourism Survey Research. Volume 1, Number 2, July 2002. ASEAN Journal on Hispitality and Tourism and Virgnia Commonwealth University, USA.

Nachrowi, dkk. 2005. Penggunaan Teknik Ekonometrik. Edisi Revisi. PT. Raja Grafindo Persada, Jakarta.

Nafziger, E.W. 1997. The Economics of Developing Countries.Third Edition. Upper Saddle River, New Jersey.

Pendit, Nyoman S. 2006. Ilmu Pariwisata. Pradnya Paramita. Jakarta.

Porter, M.E. 1994. Keunggulan Bersaing. Menciptakan dan Mempertahankan Kinerja Unggul. Binarupa Aksara, Jakarta.

Sekaran, Uma. 2006. Research Methods for Business. Metodologi Penelitian untuk Bisnis. Penerjemah : Kwan Men Yon. Penerbit Salemba Empat, Jakarta.

Seaton, A.V. and Benett, M.M. 1996. The Marketing Tourism Product : Concepts, Issues and Cases. International Thompson Business Press : London.

Silver, Christopher. 2002. Tourism and Local Economic Development in the Era of Indonesia's Decentralization. Volume 1, Number 2, July 2002. ASEAN Journal on Hispitality and Tourism and University of Illionis at Urbana-Champaign, USA.

Singh, Amrik.1998. Asia Pacific Tourism Industry : Current Trends and Future Outlook. Asia Pacific Journal of Tourism Research and University of Utah, Salt Lake City, Utah.

Sugiyono. 2004. Metode Penelitian Administrasi. Alfabeta, Bandung. 2005. Metode Peneliitan Administrasi. Alfabeta, Bandung.

Sukirno, Sadono. 2006. Ekonomi Pembangunan (Proses, Masalah dan Dasar Kebijakan).Jakarta : Kencana.

Suryana. 2000. Ekonomi Pembangunan. Jakarta : Salemba Empat.

Tambunan,T.T. 2006. Perekonomian Indonesia, Sejak Orde Lama hingga Pasca Krisis. Pustaka Quantum. Jakarta.

Tim Peneliti PMB-LIPI. 1998. Potensi Sosial Ekonomi Budaya Dalam Pengembangan Industri Pariwisata.Makalah untuk Seminar Evaluasi Proyek Pengkajian MasalahMasalah Strategis di Bidang Politik dan Sosial Budaya, Lembaga Ilmu Pengetahuan Indonesia, 24-26 March 1998. 
Todaro, M.P. 2000. Pembangunan Ekonomi di Dunia Ketiga. Alih Bahasa : Haris Munandar. Penerbit Erlangga. Jakarta.

Vellas, Francois dan Becherel, Lionel. 2008. Pemasaran Pariwisata Internasional. Suatu Pendekatan Strategis. Yayasan Obor Indonesia, Jakarta.

Wahab, S. 2003. Manajemen Kepariwisataan. Alih Bahasa : Drs. Frans Gromang. Cetakan Keempat.PT.Pradnya Paramita. Jakarta.

Wahana Komputers Seri Profesional. 2005. Pengembangan Analisis Multivatiate dengan SPSS 12. Penerbit Salemba Infotek. Jakarta.

Widjaja, HAW. 2002. Otonomi Daerah dan Daerah Otonom. PT. Raja Grafindo Persada, Jakarta.

Yoeti, Oka A. 2006. Pariwisata Budaya. Masalah dan Solusinya. Pradnya Paramita, Jakarta.

Yustika, A.E.2007. Perekonomian Indonesia Satu Dekade Pascakrisis Ekonomi. Badan Penerbit Fakultas Ekonomi Universitas Brawijaya (BPFE-Unbraw). Malang.

http://www.budpar.go.id.The Ultimate in Diversity Promotional Website.

http://www.antara.co.id. (2007). Tourism Department preparing "Visit Indonesia Year". http://www.aseanjournal.com 